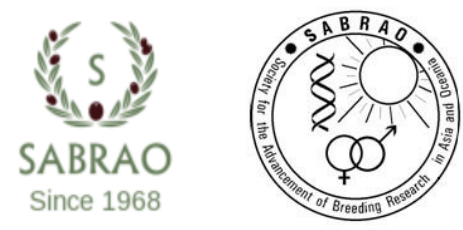

\title{
GENOTYPE BY ENVIRONMENT AND STABILITY ANALYSES OF DRYLAND MAIZE HYBRIDS
}

\author{
A. AMZERI ${ }^{1 *}$, B.S. DARYONO ${ }^{2}$ and M. SYAFII ${ }^{1}$ \\ ${ }^{1}$ Faculty of Agriculture, University of Trunojoyo Madura, Indonesia \\ ${ }^{2}$ Faculty of Biology, Gadjah Mada University, Indonesia \\ *Corresponding author email: aamzeri@gmail.com \\ Email addresses of coauthors: bs_daryono@mail.ugm.ac.id, savymohammad@gmail.com
}

\section{SUMMARY}

The phenotypic analysis of new candidate varieties at multiple locations could provide information on the stability of their genotypes. We evaluated the stability of 11 maize hybrid candidates in five districts in East Java Province, Indonesia. Maize hybrids with high yield potential and early maturity traits derived from a diallel cross were planted in a randomized complete block design with two checks (Srikandi Kuning and BISI-2) as a single factor with four replicates. The observed traits were grain yield per hectare and harvest age. The effects of environment, genotype, and genotype $\times$ environment interaction on yield were highly significant $(P<0.01)$. KTM-1, KTM-2, KTM-4, KTM-5, and KTM-6 showed higher average grain yield per hectare than the checks (Srikandi Kuning $=8.49$ ton ha ${ }^{-1}$ and BISI-2 $=$ 7.32 ton ha ${ }^{-1}$ ) at five different locations. The average harvest age of 11 candidates was less than 100 days. KTM-4 and KTM-5 had production yields that were higher than the average yield of all genotypes in all environments ( $\mathrm{Yi}>7.78$ tons ha ${ }^{-1}$ ) and were considered stable on the basis of three stability parameters, i.e., FinlayWilkinson, Eberhart-Russell, and additive main effect multiplicative interaction (AMMI). KTM-2 had the highest yield among all tested genotypes (9.33 ton ha ${ }^{-1}$ ) and was considered as stable on the basis of AMMI but not on the basis of FinlayWilkinson and Eberhart-Russell. KTM-1 performed well only in Pamekasan, whereas KTM-6 performed well only in Sampang. Thus, these two genotypes could be targeted for these specific locations.

Keywords: Grain yield, harvest age, maize hybrid, stability

Key findings: Maize hybrids KTM-2, KTM-4, and KTM-5 were identified as stable high-yielding varieties via multilocation testing and may be released as new varieties for dryland cultivation. 
Manuscript received: May 17, 2020; Decision on manuscript: August 15, 2020; Accepted: September 9, 2020. (c) Society for the Advancement of Breeding Research in Asia and Oceania (SABRAO) 2020

Communicating Editor: Dr. Akshaya K. Biswal

\section{INTRODUCTION}

The global demand for maize is increasing by 129 million tons each year (Edgerton, 2009) due to the usage of this crop not only for direct human consumption and feed but also for the production of derivatives, such as ethanol, cosmetics, soap, and many industrial products (Ranum et al., 2014; Nugroho, 2015). The increase in demand must be commensurate with the increase in productivity. Indonesia, one of the largest maize producers in Southeast Asia, produced $\sim 30$ million tons of maize in 2018 (Indonesian Statistical Center, 2019). Maize planting areas in Indonesia are generally located in dryland areas, which are not optimal for rice cultivation and horticultural commodities (Wawo et al., 2019). Given that in Indonesia, approximately $79 \%$ of the total maize cultivated area falls in dryland regions, increasing maize production is challenging (Food Crops Director-General of Indonesia, 2011). According to the Ministry of Agriculture, Republic of Indonesia (2018), maize productivity in Indonesia is 5.241 tons per hectare, which is below the average maize productivity of the 10 biggest maize producers worldwide. Thus, increasing maize productivity in dryland areas is necessary to boost maize production in Indonesia. Early-maturing varieties are expected to solve the water availability problem encountered in dryland areas wherein rainfall, the main water source, is limited (less than $2000 \mathrm{~mm} /$ year) and the rainy season is short (only 3-5 months)
(Irianto et al., 1998; Mulyani and Sarwani, 2013). Therefore, breeding programs should focus on creating new early-maturing and high-yielding varieties.

New maize varieties with high yield and early maturity can be created through hybridization (Goulet et al., 2017; Mwangangi, 2019). Previous research identified 16 potential lines through morphological and molecular characterization (Amzeri et al., 2011). Among these lines, seven were chosen as materials with high combining ability by using a full diallel mating design and regenerating 49 combinations of hybridizations (Amzeri and Badami, 2019). Eleven best hybrids for new hybrid variety candidates were identified through diallel analysis. Given that quantitative traits, such as productivity, are highly affected by the environment, candidates must be evaluated in several locations and seasons (Amzeri, 2017; Rezendra et al., 2019).

The plant phenotype is influenced by genotype, environment, and genotype $\times$ environment $(G \times E)$ interactions (Trustinah and Iswanto, 2013; Das et al., 2019). Testing variety candidates under various conditions is necessary to choose the best candidates before they are released as new varieties. Assessing the performance of new variety candidates in different locations is necessary to obtain information about their stability (Amzeri, 2015; Abate, 2020). The evaluation of candidates in dryland areas is necessary to identify the candidates that will be released. 
Stability analysis provides information regarding $G \times E$ effects and can be used be a reference for choosing a candidate variety that has stable and specific performance (Admassu et al., 2018).

The yield stability of new variety candidates can be analyzed by using various methods, such as the FinlayWilkinson, Eberhart-Russell, and additive main effect multiplicative interaction (AMMI) methods. In the Finlay-Wilkinson (1963) method, the regression coefficient is utilized to assess stability, whereas in the Eberhart-Russell (1966) method, the linear regression coefficient parameter (bi) and regression deviations $\left(\mathrm{S}_{\mathrm{di}}{ }_{\mathrm{di}}\right)$ are applied to interpret genotype stability. AMMI is a multivariate method that is often used in breeding research to measure the environmental effect on genotypes tested in multilocation trials (Mitrovic et al., 2012; Nzuvel et al., 2013). This research aimed to determine the stability of 11 hybrid maize candidates in several dryland areas.

\section{MATERIALS AND METHODS}

\section{Plant material}

Eleven hybrid maize variety candidates with high yield potential and early-maturing traits derived from a diallel cross and two checks (Srikandi Kuning and BISI-2) were used in this study (Table 1). BISI-2 is a hybrid variety that was derived from a single cross, whereas Srikandi Kuning is an open-pollinated variety (Ministry of Agriculture Republic of Indonesia, 2013). Both varieties have been widely planted by farmers in Indonesia.

Table 1. Maize genotypes used in multilocation yield trials.

\begin{tabular}{cllcll}
\hline S.No. & Code & Varieties & S.No. & Code & Varieties \\
\hline 1 & KTM-1 & UTM31 × $\times$ UTM22 & 8 & KTM-8 & UTM14 × UTM18 \\
2 & KTM-2 & UTM31 × UTM02 & 9 & KTM-9 & UTM02 × UTM18 \\
3 & KTM-3 & UTM02 × UTM14 & 10 & KTM-10 & UTM07 × UTM18 \\
4 & KTM-4 & UTM31 × UTM15 & 11 & KTM-11 & SK-1-2-5 × UTM02 \\
5 & KTM-5 & UTM31 × UTM14 & 12 & Check 1 & SrikandiKuning \\
6 & KTM-6 & UTM31 × UTM07 & 13 & Check 2 & BISI 2 \\
7 & KTM-7 & UTM31 × UTM18 & & & \\
\hline
\end{tabular}

Table 2. Description of the five research locations.

\begin{tabular}{|c|c|c|c|c|c|c|c|}
\hline \multirow{2}{*}{ Location } & \multicolumn{3}{|c|}{ Geographic position } & \multirow{2}{*}{$\begin{array}{l}\text { Mean } \\
\text { annual } \\
\text { rainfall } \\
(\mathrm{mm})\end{array}$} & \multicolumn{2}{|c|}{$\begin{array}{l}\text { Temperature } \\
\left({ }^{\circ} \mathrm{C}\right)\end{array}$} & \multirow{2}{*}{ - Soil type } \\
\hline & Longitude & Latitude & Altitude & & Min & Max & \\
\hline Kamal, Bangkalan & $112^{\circ} 44 \mathrm{E}$ & $7^{\circ} 07 \mathrm{~S}$ & $5 \mathrm{~m}$ & 269 & 28 & 32 & Grumusol \\
\hline Jrengik, Sampang & $113^{\circ} 08 \mathrm{E}$ & $7^{\circ} 07 \mathrm{~S}$ & $25 \mathrm{~m}$ & 848 & 28 & 32 & Grumusol \\
\hline Pademawu, Pamekasan & $113^{\circ} 31 \mathrm{E}$ & $7^{\circ} 10 \mathrm{~S}$ & $7 \mathrm{~m}$ & 1287 & 28 & 30 & Aluvial \\
\hline Lenteng, Sumenep & $113^{\circ} 45 \mathrm{E}$ & $7^{\circ} 02 \mathrm{~S}$ & $50 \mathrm{~m}$ & 1828 & 26 & 31 & Litosol \\
\hline Leces, Probolinggo & $113^{\circ} 14 \mathrm{E}$ & $7^{\circ} 52 \mathrm{~S}$ & $54 \mathrm{~m}$ & 1673 & 26 & 33 & Aluvial \\
\hline
\end{tabular}




\section{Research implementation}

This research was conducted during the February-June 2019 rainy season at five districts in East Java Province, Indonesia, i.e., Bangkalan, Sampang, Pamekasan, Sumenep, and Probolinggo (Table 2). A randomized complete block design was used with 13 genotypes as a single factor and four replications for a total of 52 experimental units in each location. Each genotype was planted in a plot with a size of $2 \mathrm{~m} \times 5 \mathrm{~m}$ with a spacing of $70 \mathrm{~cm} \times 20 \mathrm{~cm}$. Each square contained 100 plants. Fertilization was carried out in three stages: (1) at 7 days after planting (DAP), i.e., $100 \mathrm{~kg} \mathrm{ha}^{-1}$ urea, $200 \mathrm{~kg}$ $\mathrm{ha}^{-1} \mathrm{SP}-36$, and $50 \mathrm{~kg} \mathrm{ha}^{-1} \mathrm{KCl}$; (2) at 25 DAP, i.e., $100 \mathrm{~kg} \mathrm{ha}^{-1}$ urea and 50 $\mathrm{kg} \mathrm{ha}^{-1} \mathrm{KCl}$; and (3) at 40 DAP (100 $\mathrm{kg} \mathrm{ha}^{-1}$ urea).

Harvesting was done after the maize reached physiological maturity or after the husk had dried and turned brown in color, at which stage the kernels had hardened and started to a build black layer at least in $50 \%$ of each kernel line. At this time point, moisture content was less than $30 \%$. The data obtained by this measurement were converted into maize yield production per hectare when the moisture content was $15 \%$ by using the following formula:

$$
Y=\frac{10,000}{H A} \times \frac{100-M C}{100-15} \times G W,
$$

where $Y$ is the grain yield $(\mathrm{kg}$ $\left.\mathrm{ha}^{-1}\right), \mathrm{HA}$ is the harvested area per plot $\left(m^{2}\right), M C$ is the moisture content at harvest time $(\%)$, and GW is the harvested grain weight per plot $(\mathrm{kg})$. In addition to the parameters of maize production per hectare, harvest age parameters were also calculated for each genotype in each location.

\section{Combined analysis over location}

Maize production per hectare and time to harvest were analyzed through variance analysis in each location and combined variance analysis. In case of significant differences, Duncan multiple range test (DMRT) was performed (Gomez and Gomez, 1984). Moreover, stability analysis was conducted to check for $G \times E$ interactions. Statistical analysis was carried out by using SAS 9.0, PBSTATGE, and STAR programs. Stability analysis in this research used the regression coefficients proposed by Finlay and Wilkinson (1963) and Eberhart and Russell (1966). Furthermore, the AMMI method was used to explain $G \times E$ interactions. This method provides the relative position distribution of the genotype to the environment such that the suitability of the locations for the genotype can be clearly mapped (Hongyu et al., 2014).

\section{Finlay-Wilkinson stability}

This analysis is based on regression between genotypes with the mean of genotype in each environment. The expressions of the genotype stability in the environments are shown by the values of $b i=1, b i<1$, and $b i>1$, which are the representative expressions of average, high, and low stabilities, respectively. The regression coefficient (bi) was calculated by using the formula

$$
b_{i}=\frac{\sum_{j=1}^{q}\left(\bar{X}_{i j}-\bar{X}_{i .}\right)\left(\bar{X}_{j .-}-\bar{X}_{. .}\right)}{\sum_{j=1}^{q}\left(\bar{X}_{j .}-\bar{X}_{. .}\right)^{2}}
$$


where $b_{i}$ is the $i^{\text {th }}$ genotype regression coefficient, $\bar{X}_{\mathrm{ij}}$ is the mean value of the $i^{\text {th }}$ genotype in the $j^{\text {th }}$ environment, $\bar{X}_{i}$. is the mean value of the $\mathrm{i}^{\text {th }}$ genotype, $\bar{X} \mathrm{j}$. is the mean value of the $j^{\text {th }}$ environment, $X .$. is the mean value of all environmental indices, and $q$ is the number of environments.

\section{Eberhart-Russell stability}

This analysis uses the mean squares of deviations from regression $\left(S^{2}{ }_{\text {di }}\right)$ to measure the stability of a genotype. A genotype is considered stable if its mean square residual from the regression model at the environment index is small.

$$
S_{d i}^{z}=\frac{1}{q-2}\left[\left(\sum_{j=1}^{q} X i j^{2}\right)-\left(\frac{\left(\sum_{j=1}^{q} X i j I j\right)^{2}}{\sum_{j=1}^{q} I^{2}}\right)\right],
$$

where $\mathrm{S}_{\mathrm{di}}^{2}$ is the square of deviations from regression, $X_{i j}$ is the mean value of the $i^{\text {th }}$ genotype in the $j^{\text {th }}$ environment, $I_{j}$ is the $j^{\text {th }}$ environment index, and $\mathrm{q}$ is the number of environments.

\section{AMMI}

The AMMI method combines the additive effects on variance analysis and the multiplicative effect on the analysis of the main components. The assumption that must be fulfilled in AMMI is that the error must have normal distribution and homogeneous variance. AMMI can explain $G \times E$ interactions through the relative distribution pattern against the environment. AMMI biplots can be used to analyze the relationship among genotype, environment, and G $\times \quad \mathrm{E}$ interactions (Mattjik and Sumertajaya, 2002). The linear model of AMMI is given by ${ }^{-}$

$$
Y_{g e r}=\mu+\alpha_{g}+\beta_{\varepsilon}+\Sigma \sqrt{\lambda_{n}} \varphi_{g n} \rho_{e n}+\delta_{g e}+\varepsilon_{g e r},
$$

where $Y_{\text {ger }}$ is the yield of the $g^{\text {th }}$ genotype of the $r^{\text {th }}$ replicate in the $e^{\text {th }}$ environment; $\mu$ is the grand mean; $a_{g}$ is the genotype mean deviation; $\beta_{\mathrm{e}}$ is the environment mean deviation; $\lambda_{\mathrm{n}}$ is the singular value for the PCA axis $n$; $\varphi_{g n}$ and $\rho_{e n}$ are the genotype and environment PCA score for the PCA axis $n$, respectively; $\delta_{g e}$ is the standard deviation from the linear model; and $\varepsilon_{\text {ger }}$ is the random effect of the $g^{\text {th }}$ genotype of the $r^{\text {th }}$ replicate in $\mathrm{e}^{\text {th }}$ environment.

\section{RESULTS AND DISCUSSION}

The results of the combined variance analysis of the yield per hectare of 11 hybrid variety candidates and two checks showed that the effect of environment, genotype, and $\mathrm{G} \times \mathrm{E}$ interaction was statistically significant (Table 3). The contributions of environment, genotype, and their interaction to the yield were $25.71 \%$, $32.32 \%$, and $19.24 \%$, respectively. Therefore, production was dependent on genotype and environmental conditions (Djufry and Lestari, 2012). The occurrence of $G \times E$ interactions caused the tested genotypes to show variation in different environments (Bocianowski et al., 2019; Haruna et al., 2017).

The degree of the variability of the tested genotypes was affected by the yield in five different locations (Figure 1). Yield showed narrow variability in Probolinggo, whereas 
SABRAO J. Breed. Genet. 52 (4) 355-368

Table 3. AMMI analysis of variance for yield.

\begin{tabular}{llllll}
\hline Source of variance & d.f. & SS & MS & F-value & $\begin{array}{l}\text { \% Variance } \\
\text { explained }\end{array}$ \\
\hline Environments (E) & 4 & 25.08 & 6.27 & $112.36^{* *}$ & 25.71 \\
Replications (Environ.) & 15 & 0.84 & 0.06 & $1.21^{\mathrm{ns}}$ & 9.42 \\
Genotypes (G) & 12 & 687.59 & 57.30 & $92.83^{* *}$ & 32.32 \\
G $\times$ E & 48 & 29.63 & 0.62 & $13.37^{* *}$ & 19.42 \\
IPC1 & 15 & 19.35 & 1.29 & $27.96 * *$ & 65.29 \\
IPC2 & 13 & 5.78 & 0.44 & $9.64^{* *}$ & 19.54 \\
IPC3 & 11 & 3.83 & 0.35 & $7.55^{* *}$ & 12.94 \\
IPC4 & 9 & 0.66 & 0.07 & $1.58^{\text {ns }}$ & 2.23 \\
Error & 180 & 8.31 & 0.05 & & \\
Total & 259 & 751,43 & & & \\
\hline
\end{tabular}

Note : $\mathrm{E}=$ Environment (location); IPC $=$ Interaction Principal Component Analysis; $* *=$ significant at the a level of $<0.01 ; \mathrm{ns}=$ nonsignificant; $\mathrm{df}=$ degrees of freedom; $\mathrm{SS}=$ Sum of squares; $\mathrm{MS}=$ mean squares.

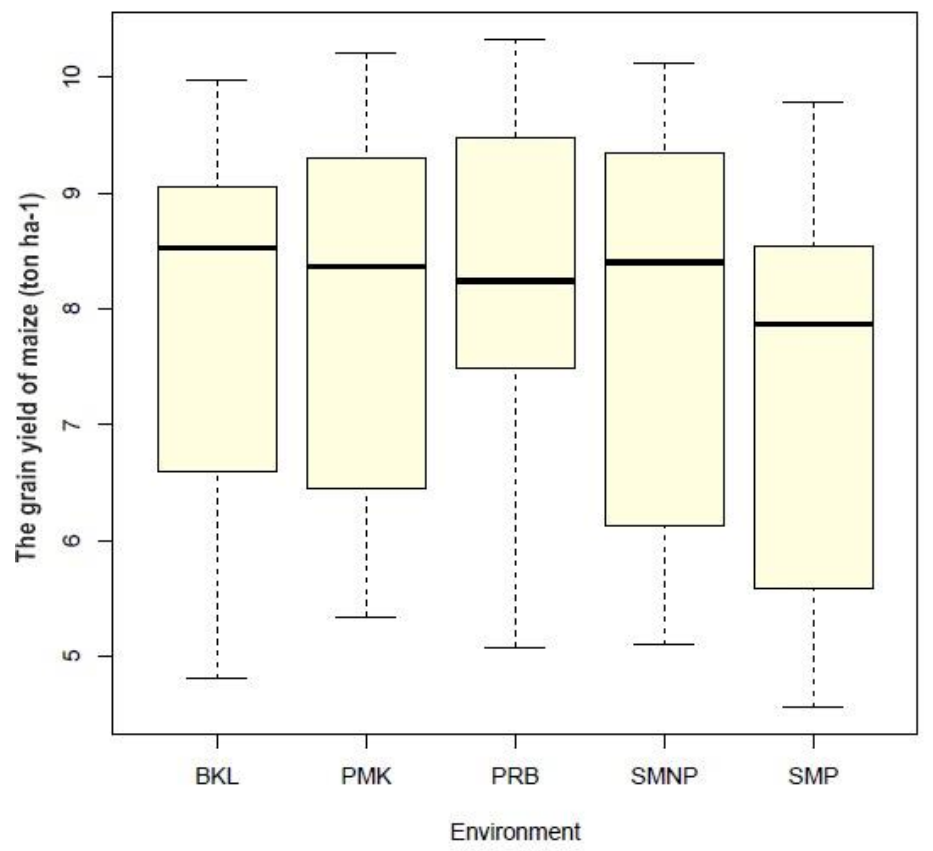

Figure 1. Grain yield of tested genotypes at five different dryland locations.

broad variability was observed in Sumenep. The inconsistency shown by variability among locations was influenced by the adaptation capability of a genotype to environmental factors. The capability of plant adaptation to the environment is caused by a number of combinations of plant traits that can cope with environmental changes such that the final yield of plants is unaffected (Lestari et al., 2010).

The average of maize production per hectare in this experiment was approximately 4.8110.33 ton $\mathrm{ha}^{-1}$ (Table 4). The KTM-2 
Table 4. Grain yield (ton ha ${ }^{-1}$ ) of 13 maize genotypes at five locations.

\begin{tabular}{|c|c|c|c|c|c|c|}
\hline \multirow{3}{*}{ Genotypes } & \multicolumn{5}{|c|}{ Locations } & \multirow{2}{*}{ Mean } \\
\hline & $\mathrm{BKL}$ & SMP & PMK & SMNP & PRB & \\
\hline & \multicolumn{6}{|c|}{ Grain yield (ton ha ${ }^{-1}$ ) } \\
\hline KTM-1 & $9.05^{a b c}$ & $8.15^{b c}$ & $9.93^{\mathrm{ab}}$ & $9.35^{b}$ & $10.18^{a}$ & $9.33^{a b c}$ \\
\hline KTM-2 & $9.97^{\mathrm{a}}$ & $8.98^{a b}$ & $10.20^{a}$ & $10.12^{\mathrm{a}}$ & $10.33^{a}$ & $9.92^{a}$ \\
\hline KTM-3 & $5.58^{e f}$ & $4.56^{f}$ & $6.20^{\mathrm{fg}}$ & $6.06^{\mathrm{e}}$ & $7.49^{d}$ & $5.98^{f}$ \\
\hline KTM-4 & $9.07^{a b c}$ & $8.54^{b c}$ & $9.30^{c}$ & $9.18^{b}$ & $9.25^{b}$ & $9.07^{c}$ \\
\hline KTM-5 & $8.87^{a b}$ & $8.76^{b c}$ & $9.28^{c}$ & $9.35^{b}$ & $9.48^{b}$ & $9.15^{b c}$ \\
\hline KTM-6 & $9.76^{a b}$ & $9.78^{a}$ & $9.51 \mathrm{bc}$ & $9.60^{b}$ & $10.16^{a}$ & $9.76^{a b}$ \\
\hline KTM-7 & 6.59 ed & $5.58^{\mathrm{e}}$ & $6.44^{f}$ & $6.07^{\mathrm{e}}$ & $5.57^{\mathrm{e}}$ & $6.05^{f}$ \\
\hline KTM-8 & $5.03^{f}$ & 4.82 ef & $6.30^{f}$ & $6.13^{\mathrm{e}}$ & $5.80^{e}$ & $5.62^{\mathrm{fg}}$ \\
\hline KTM-9 & $4.81^{f}$ & $4.85^{\text {ef }}$ & $5.34^{\mathrm{g}}$ & $5.10^{f}$ & $5.08^{c}$ & $5.03^{g}$ \\
\hline KTM-10 & $8.65^{c}$ & $7.87^{c}$ & $8.37^{d}$ & $8.45^{c}$ & $8.24^{c}$ & $8.31^{d}$ \\
\hline KTM-11 & 6.68 ed & $6.62^{d}$ & $7.26^{\mathrm{e}}$ & $7.31^{d}$ & $7.62^{d}$ & $7.10^{\mathrm{e}}$ \\
\hline Srikandi Kuning & $8.53^{c}$ & $8.54^{b c}$ & $8.58^{d}$ & $8.40^{c}$ & $8.41^{c}$ & $8.49^{d}$ \\
\hline BISI-2 & $7.37^{d}$ & $6.90^{d}$ & $7.35^{\mathrm{e}}$ & $7.16^{d}$ & $7.85^{\mathrm{cd}}$ & $7.32^{\mathrm{e}}$ \\
\hline Environment mean yield & 7.69 & 6.90 & 8.00 & 7.87 & 8.11 & 7.78 \\
\hline CV $(\%)$ & 10.70 & 10.21 & 8.75 & 9.62 & 8.40 & 9.22 \\
\hline
\end{tabular}

Note: Numbers in one column followed by the same letter show no significant difference based on the DMRT test at $a=0.05 ; B K L=$ Bangkalan; SMP = Sampang; PMK = Pamekasan; SMNP = Sumenep; $\mathrm{PRB}=$ Probolinggo.

genotype showed the highest yield in four different locations: Bangkalan (9.97 ton ha $\left.{ }^{-1}\right)$, Pamekasan $(10.20$ ton ha $\left.{ }^{-1}\right)$, Sumenep $\left(10.12\right.$ ton $\left.\mathrm{ha}^{-1}\right)$, and Probolinggo (10.33 ton ha ${ }^{-1}$ ). KTM- 6 showed the highest production only in Sampang (9.78 ton ha- ${ }^{1}$ ). KTM-1, KTM-2, KTM-4, KTM-5, and KTM- 6 showed higher yield per hectare than the check variety in five different locations.

The average harvest age of the tested genotypes was 75-102 days (Table 5). At five locations, KTM-11 showed the shortest average harvest age, which ranged from 75-80 days and was shorter than the average harvest age of the check varieties (Srikandi Kuning and BISI-2). The other candidates also had a short time to harvest of less than 100 days. Oluwaranty et al. (2015) classified maize plants that have harvest ages of 85-90 days as very early maturing maize. Furthermore, maize aged <
110 days is classified as earlymaturing (Subedi and $\mathrm{Ma}, 2011$ ). Therefore, KTM-11 was categorized as a very early maturing maize variety, and the 10 other hybrid maize candidates were early maturing and are suitable for planting in dryland areas with limited water sources.

\section{Finlay-Wilkinson stability}

In the Finlay-Wilkinson method, $b i$ is used as a stability parameter, wherein a regression coefficient value of 1 represents stability. A regression coefficient value of less than 1 indicates that the genotype has above-average stability, whereas a regression coefficient value of more than 1 indicates that the genotype has below-average stability (Finlay and Wilkinson, 1963). A bi value with high variation will facilitate the selection of stable genotypes by breeders. 
Table 5. Harvest age (days) of 13 maize genotypes at five locations.

\begin{tabular}{|c|c|c|c|c|c|c|}
\hline \multirow{3}{*}{ Genotypes } & \multicolumn{5}{|c|}{ Locations } & \multirow{2}{*}{ Mean } \\
\hline & $\mathrm{BKL}$ & SMP & PMK & SMNP & PRB & \\
\hline & \multicolumn{6}{|c|}{ Harvest age (days) } \\
\hline KTM-1 & $90.00^{b}$ & $88.00^{b}$ & $90.00^{b}$ & $90.00^{b}$ & $97.00^{b}$ & $91.00^{b}$ \\
\hline KTM-2 & $89.00^{b c}$ & $87.00^{b}$ & $90.00^{b}$ & $90.00^{b}$ & $96.00 \mathrm{bc}$ & $90.40^{b c}$ \\
\hline KTM-3 & $86.00^{c}$ & $86.00^{b}$ & $90.00^{b}$ & $90.00^{b}$ & $92.00 \mathrm{bcd}$ & 88.80 bc \\
\hline KTM-4 & $88.00^{b c}$ & $87.00^{b}$ & $90.00^{b}$ & $90.00^{b}$ & $92.00 \mathrm{bcd}$ & 89.40 bc \\
\hline KTM-5 & $88.00^{b c}$ & $87.00^{b}$ & $88.00^{b}$ & $89.00^{b c}$ & $91.00^{\mathrm{cd}}$ & $88.60^{b c}$ \\
\hline KTM-6 & $90.00^{b}$ & $89.00^{b}$ & $90.00^{b}$ & $90.00^{b}$ & $95.00 \mathrm{bcd}$ & 90.80 bc \\
\hline KTM-7 & $89.00^{b c}$ & $88.00^{b}$ & $89.00^{b}$ & $90.00^{b}$ & $95.00 \mathrm{bcd}$ & $90.20 \mathrm{bc}$ \\
\hline KTM-8 & $89.00^{b c}$ & $88.00^{b}$ & $90.00^{b}$ & $90.00^{b}$ & $94.00 \mathrm{bcd}$ & $90.20 \mathrm{bc}$ \\
\hline KTM-9 & $89.00^{b c}$ & $89.00^{b}$ & $90.00^{b}$ & $90.00^{b}$ & $94.00 \mathrm{bcd}$ & $90.40^{b c}$ \\
\hline KTM-10 & 89.00 bc & $88.00^{b}$ & $88.00^{b}$ & $89.00^{b c}$ & $94.00 \mathrm{bcd}$ & $89.60^{b c}$ \\
\hline KTM-11 & $77.00^{d}$ & $75.00^{c}$ & $77.00^{\mathrm{c}}$ & $77.00^{d}$ & $80.00^{e}$ & $77.20^{d}$ \\
\hline Srikandi Kuning & $87.00^{b c}$ & $86.00^{b}$ & $87.00^{b}$ & $86.00^{c}$ & $90.00^{d}$ & $87.20^{b c}$ \\
\hline BISI-2 & $95.00^{a}$ & $94.00^{a}$ & $98.00^{a}$ & $97.00^{a}$ & $102.00^{a}$ & $97.20^{a}$ \\
\hline Environment mean yield & 88.15 & 87.08 & 89.00 & 89.08 & 93.23 & 89.31 \\
\hline CV $(\%)$ & 8.62 & 9.81 & 8.61 & 8.45 & 10.42 & 8.44 \\
\hline
\end{tabular}

Note: Numbers in one column followed by the same letter show no significant difference based on the DMRT test at $a=0.05 ; B K L=$ Bangkalan; SMP = Sampang; PMK = Pamekasan; SMNP = Sumenep; $\mathrm{PRB}=$ Probolinggo.

Table 6. Mean grain yields, harvest age (days), and yield stability estimates of stability for the yield of 13 maize genotypes at five locations.

\begin{tabular}{|c|c|c|c|c|}
\hline Genotypes & $\begin{array}{l}Y_{i} \\
\left(\text { ton ha }{ }^{-1} \text { ) }\right.\end{array}$ & $\begin{array}{l}\text { Harvest age } \\
\text { (days) }\end{array}$ & $\begin{array}{l}b_{i} \\
\text { (Finlay and } \\
\text { Wilkinson) }\end{array}$ & $\begin{array}{l}S_{d i}^{2} \\
\text { (Eberhart and } \\
\text { Russell) }\end{array}$ \\
\hline KTM-1 & $9.33^{a b c}$ & $91.00^{b}$ & $2.27 * *$ & $0.01^{\mathrm{ns}}$ \\
\hline KTM-2 & $9.92^{\mathrm{a}}$ & 90.40 bc & $1.52 *$ & $0.01^{\text {ns }}$ \\
\hline KTM-3 & $5.98^{f}$ & 88.80 bc & $2.86 * *$ & $0.17 * *$ \\
\hline KTM-4 & $9.07^{c}$ & $89.40^{b c}$ & $0.86^{\text {ns }}$ & $0.00^{\mathrm{ns}}$ \\
\hline KTM-5 & $9.15^{b c}$ & $88.60^{b c}$ & $0.82^{\mathrm{ns}}$ & $0.01^{\mathrm{ns}}$ \\
\hline KTM-6 & $9.76^{a b}$ & $90.80 \mathrm{bc}$ & $0.11^{* *}$ & $0.07 * *$ \\
\hline KTM-7 & $6.05^{f}$ & 90.20 bc & $0.29 * *$ & $0.27 * *$ \\
\hline KTM-8 & $5.62 \mathrm{fg}$ & $90.20^{b c}$ & $1.56 *$ & $0.18 * *$ \\
\hline KTM-9 & $5.03^{\mathrm{g}}$ & $90.40^{b c}$ & $0.44^{*}$ & $0.02^{\mathrm{ns}}$ \\
\hline KTM-10 & $8.31^{d}$ & 89.60 bc & $2.27 * *$ & $0.07 * *$ \\
\hline KTM-11 & $7.10^{\mathrm{e}}$ & $77.20^{d}$ & $0.45^{*}$ & $0.04 * *$ \\
\hline Srikandi Kuning & $8.49^{d}$ & $87.20^{b c}$ & $-0.10 * *$ & $0.00^{\mathrm{ns}}$ \\
\hline BISI-2 & $7.32^{\mathrm{e}}$ & $97.20^{a}$ & $0.83^{\text {ns }}$ & $0.04 * *$ \\
\hline
\end{tabular}

Noted: $Y_{i}=$ Yield means over all environments; $b i=$ coefficient of regression; $\mathrm{S}_{\mathrm{di}}^{2}=$ sum of squares deviation from regression; $\mathrm{ns}=$ nonsignificant; ${ }^{*}=$ significantly different from $1 ; * *=$ significantly different from 0. 


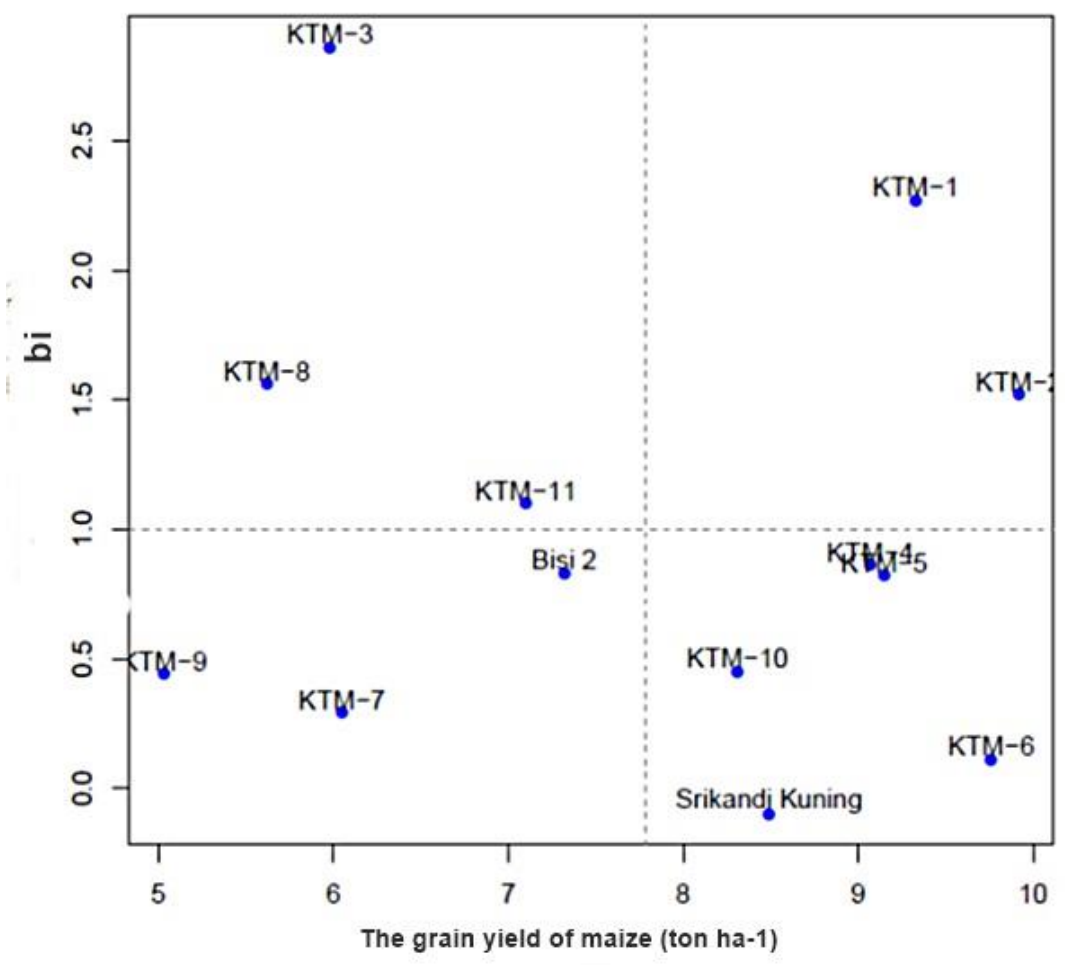

Figure 2. Plot of regression coefficient $\left(b_{i}\right)$ vs yield means over all environments $\left(Y_{i}\right)$.

The results for the 13 maize genotypes cultivated in five different locations showed that KTM-4, KTM-5, and BISI-2 were categorized as stable genotypes because their bi values were not significantly different from 1 (Table 6; Figure 2). The bi values of KTM-1, KTM-2, KTM-3, KTM-8, KTM11 , and Srikandi Kuning were $<1$ and were significantly different. Thus, these genotypes were considered as genotypes that had adapted well to a marginal environment.

\section{Eberhart-Russell stability}

In the Eberhart-Russell method, the regression coefficient $b i$ and regression deviation $S^{2}{ }_{d i}$ are used to determine genotype stability. A genotype is considered as stable if its bi value is not significantly different from 1 and its $S^{2}$ di value is close to 0 . bi $\neq 1$ shows that the genotype interacts with the environment even if its regression coefficient $=1$. KTM-4 and KTM-5 had regression coefficients that were significantly different from 1 and a regression deviation that was close to 0 . Therefore, these genotypes were categorized as stable. The regression coefficient value against regression deviation showed that KTM1 and KTM2 had high yield stability in the optimum environment (Table 6).

\section{AMMI analysis}

AMMI analysis is done to check for significant $G \times E$ interactions. AMMI provides an illustration of $G \times E$ interaction and stability 
(Purbokurniawan et al., 2014). AMMI analysis showed that the $\mathrm{G} \times \mathrm{E}$ interaction effect was as follows: The contributions of the interaction effects of each component of IPC1 to IPC4 were $65.29 \%, 19.54 \%, 12.94 \%$, and $2.23 \%$ (Table 3 ). The values of these contributions indicated that the components of IPC1 and IPC2 had a dominant role in explaining the effect of interactions, which was equal to $81.83 \%$.

An AMMI biplot was used to interpret the AMMI model. PC1 vs. PC2 can illustrate stable genotypes or genotypes that can perform well in specific locations. Genotypes near the environment line shows a close relationship between genotype with the environment, where the environment provides support to the genotypes. Furthermore, the genotype closest to the central point (coordinate 0.0 ) has high stability. KTM-2, KTM-4, KTM-5, KTM-9, and KTM-11 approached the coordinates. Thus, these genotypes were classified as stable and widely adaptable genotypes (general adaptation) (Figure 3). KTM1 was close to the environment line (Pamekasan, Sumenep, and Probolinggo). KTM-3 was near Probolinggo; KTM-6 was near Sampang; and KTM-7 was near Pamekasan, Bangkalan, and Sumenep. KTM-8 was close to Pamekasan and Sumenep, and KTM 10 was near Bangkalan. Srikandi Kuning was close to Sampang and Bangkalan, and BISI-2 was close to Sampang and Probolinggo. Eight

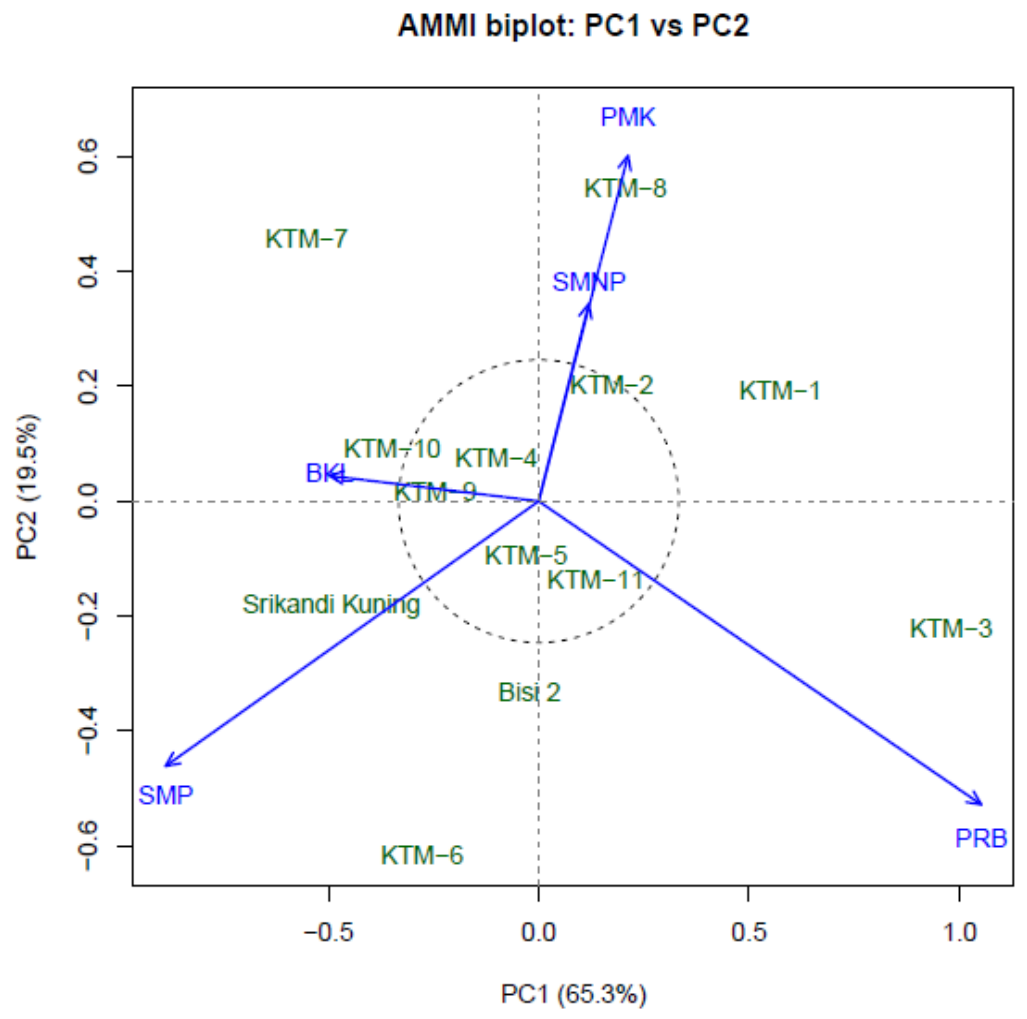

Figure 3. Biplot of the interaction of PC1 and PC2 for maize production. 
Table 7. Genotype stability of 13 maize genotypes at five locations.

\begin{tabular}{lllll}
\hline Genotypes & $Y_{i}$ & Finlay-Wilkinson & $\begin{array}{l}\text { Eberhart- } \\
\text { Russell }\end{array}$ & AMMI \\
\hline KTM-1 & 9.33 & Below-average stability & Unstable & Specific \\
KTM-2 & 9.92 & Below-average stability & Unstable & Stable \\
KTM-3 & 5.98 & Below-average stability & Unstable & Specific \\
KTM-4 & 9.07 & Average stability & Stable & Stable \\
KTM-5 & 9.15 & Average stability & Stable & Stable \\
KTM-6 & 9.76 & Above-average stability & Unstable & Specific \\
KTM-7 & 6.05 & Above-average stability & Unstable & Specific \\
KTM-8 & 5.62 & Below-average stability & Unstable & Specific \\
KTM-9 & 5.03 & Above-average stability & Unstable & Stable \\
KTM-10 & 8.31 & Below-average stability & Unstable & Specific \\
KTM-11 & 7.10 & Above-average stability & Unstable & Stable \\
Srikandi Kuning & 8.49 & Above-average stability & Unstable & Specific \\
BISI-2 & 7.32 & Average stability & Stable & Specific \\
\hline
\end{tabular}

Note: $Y i=$ Yield means over all environments.

genotypes, i.e., KTM-1, KTM-3, KTM6, KTM-7, KTM-8, KTM-10, Srikandi Kuning, and BISI-2, were grouped as specific genotypes with narrow adaptation (specific adaptation) that could perform well only in specific locations.

\section{Combined stability analyses}

Finley-Wilkinson regression analysis and the Eberhart-Russell method can effectively describe genotype response in diverse environments; however, these approaches only explain linear components and ignores diversity if a component is nonlinear (Widyastuti et al., 2013). AMMI can explain $\mathrm{G} \times \mathrm{E}$ interaction. AMMI biplots can also be used to visualize the characteristics of tested genotypes for checking whether they are stable in all locations or only at a certain location (Gauch et al., 2008). Finley-Wilkinson, EberhartRussell, and AMMI characterized KTM4 and KTM-5 as stable (Table 7). Both genotypes had an average yield exceeding the average of all genotypes in all environments ( $\mathrm{Yi}>$ 7.78 ton $\mathrm{ha}^{-1}$ ). In addition, both genotypes had early maturity (KTM-4 $=89.40$ days and $\mathrm{KTM}-5=88.60$ days). Therefore, both genotypes can be recommended as varieties with high production characteristics, early maturity, stability, and very broad adaptation. KTM-2 was the genotype with the highest average yield in five different locations among all other genotype (9.33 ton ha ${ }^{-1}$ ) and early harvest time (90.40 days). FinlayWilkinson and Eberhart-Russell stability analysis results indicated that KTM-2 was unstable, whereas AMMI stability analysis indicated that this variety was stable. Therefore, KTM-2 could be released as a variety with high production and early maturity. KTM- 1 and KTM- 6 had high production rates of 9.33 and 9.76 tons $\mathrm{ha}^{-1}$, respectively, but narrow adaptation. KTM-1 performed well at Pamekasan, and KTM-6 performed well at Sampang. Thus, both genotypes can be developed in these environments. 


\section{CONCLUSIONS}

The effects of environment, genotype, and $G \times E$ interaction on yield were highly significant $(P<0.01)$. KTM-1, KTM-2, KTM-4, KTM-5, and KTM-6 showed higher grain yield per hectare than the check at five different locations. The average harvest age of 11 maize variety candidates was less than 100 days. KTM-4 and KTM-5 had production yields above the average yield of all genotypes in all environments $\left(\mathrm{Yi}>7.78\right.$ tons $\mathrm{ha}^{-1}$ ) and were considered stable in three stability analyses, i.e., FinlayWilkinson, Eberhart-Russell, and AMMI. KTM-2 had the highest yield among the tested genotypes (9.33 ton $\mathrm{ha}^{-1}$ ) and was considered as stable on the basis of AMMI but not on the basis of the Finlay-Wilkinson and EberhartRussell methods. KTM-1 performed well only in Pamekasan, whereas KTM6 also well performed in Sampang. Therefore, these two genotypes may be deployed in those specific locations.

\section{ACKNOWLEDGEMENTS}

The author thanks the University of Trunojoyo Madura, Indonesia, for funding this research through the University's Independent Research Scheme.

\section{REFERENCES}

Abate M (2020). Genotype by environment interaction and yield stability analysis of open pollinated maize varieties using AMMI model in Afar Regional State, Ethiopia. J. Plant Breed. Crop Sci. 12(1): 8-15.

Admassu S, Nigussie M, Zelleke H (2008). Genotype environment interaction and stability analysis for grain yield of maize (Zea mays. L) in Ethiopia. Asian J. Plant Sci. 7(2): 163-169.
Amzeri A, Indradewa D, Daryono BS, Rachmawati D (2011). Phenetic and genetic relationships among madura local maize (Zea mays L.) revealed by morphological characters and RAPD markers.Biota. 16(2): 227-235.

Amzeri A (2015). Plant Breeding Basics. UTM-Press. Bangkalan, Indonesia.

Amzeri A (2017). Yield evaluation of ten "Madura" promising hybrid maize with high productivity and early maturity. Agrovigor. 10(1): 73-79.

Amzeri A, Badami K (2019). Estimation of combining ability, heritability and genes action of yield components of inbred corn lines in diallel crosses. $\quad 2^{\text {nd }}$ International Conference on Social Science. Atlantis Press, pp. 1212-1216.

Bocianowski J, Nowosad K, Tomkowiak A (2019). Genotype-environment interaction for seed yield of maize hybrids and lines using the AMMI model. Maydica. 64: 1-8.

Das AK, Muthusamy $V$, Zunjare RU, Chauhan HS, Sharma PK, Bhat JS, Guleria SK, Saha S, Hossain F (2019). Genetic variability, genotype $x$ environment interactions and combining abilityanalysis of kernel tocopherols among maize genotypes possessing novel allele of $y$-tocopherol methyl transferase (ZmVTE4). J. Cereal Sci. 86:1-8.

Djufry F, Lestari MS (2012). Yield stability and adaptability genotype of hybrids maize dry tolerant using additive main effect multiplicative interaction (AMMI) methods. $J$. Informatika Pertanian. 21(2): 8387.

Eberhart SA, Russell WA (1966). Stability parameters for comparing varieties. Crop Sci. 6: 36-40.

Edgerton MD (2009). Increasing crop productivity to meet global needs for feed, food, and fuel. Plant Physiol. 149: 7-13.

Finlay KW, Wilkinson GN (1963). The analysis of adaptation in a plant- 
breeding programme. Aust. J. Agric. Res. 14: 742-754.

Food Crops Director-General of Indonesia (2011). Maize cultivation technology. Directorate of Serealia Cultivation of Indonesian Agriculture Ministry.

Gauch HG, Piepho HP, Annicchiarico P (2008). Statistical analysis of yield trials by AMMI and GGE: Further considerations. Crop Sci. 48: 866889.

Gomez KA and Gomez AA (1984). Statistical procedures for agricultural research (2 ed.). John Wiley and Sons, New York.

Goulet BE, Roda F, Hopkins R (2017). Hybridization in plants: Old Ideas, New Techniques. Plant Physiol. 173(1): 65-78.

Haruna A, Adu GB, Buah SS, Kanton RAL, Kudzo AI, Seidu AM, Kwadwo OA (2017). Analysis of genotype by environment interaction for grain yield of intermediate maturing drought tolerant top-cross maize hybrids under rain-fed conditions. Cogent Food and Agric. . $3: 1-13$

HongyuK, Garcia-Pena M, de Araujo LB, Dias CTD (2014). Statistical analysis of yield trials by AMMI analysis of genotype $x$ environment interaction. Biomet. Letters. 51(2): 89-102.

Indonesian Statistical Center (2019). Report on Indonesia's harvested area, productivity and maize production in 2014-2018. Jakarta, Indonesia.

Irianto G, Sosiawan H, Karama S (1998). Development strategy for dryland agriculture to anticipate global competition. Proceedings of the Discussion and Communication Meeting on Soil and Agro-climate Research Results. Puslittanak, Bogor. pp. 1-12.

Lestari AP, Abdullah B, Junaedi A, Aswidinnoor (2010). Yield stability and adaptability of aromatic new plant type (NPT) rice lines. $J$. Agron. Indonesia. 38(3): 199-204.
Mattjik AA, Sumertajaya IM (2002). Design of Experiments with SAS and Minitab Applications. IPB Press. Bogor, Indonesia.

Ministry of Agriculture Republic of Indonesia (2018). Production, harvest area and productivity of palawija in Indonesia, 2014 2018. Ministry of Agriculture Republic of Indonesia.

Ministry of Agriculture Republic of Indonesia (2013). Description of Superior Maize Varieties. Agricultural Research and Development Agency. Ministry of Agriculture Republic of Indonesia.

Mitrovic B, Stanisavljevi D, Treski, S, Stojakovic M, Ivanovic M, Bekavac G, Rajkovic M (2012). Evaluation of experimental maize hybrids tested in multi-location trials using AMMI and GGE biplot analysis. Turkish $J$. Field Crops. 17(1): 35-40.

Mulyani A, Sarwani M (2013). Characteristics and potential of suboptimal land for agricultural development in Indonesia. $J$. Sumberdaya Lahan. 7(1): 47-58.

Mwangangi IM, Muli JK, Neondo JO (2019). Plant hybridization as an alternative technique in plant breeding improvement. Asian $J$. Res. in Crop Sci. 4(1): 1-11.

Nugroho BA (2015). Analysis of production functions and efficiency of corn at Patean District, Kendal Regency. Jejak. 8(2):160-172.

Nzuve F, Githiri S, Mukunya DM, Gethi J (2013). Analysis of genotype $x$ environment interaction for grain yield in maize hybrids. J. Agric. Sci. 5(11): 75-85.

Oluwaranti A, Fakorede MAB, Adeboye FA (2015). Maturiygroups and phenologu of maize in a rainforest location. Int. J. Agric. Innov. Res.4(1): 124-127.

Purbokurniawan, Purwoko BS, Wirnas D, Dewi IS (2014). Yield potential and stability, and adaptability of new plant type of upland rice lines developed through anther culture. J. Agron. Indonesia 42(1): 9-16. 
Ranum P, Pena-Rosas JP, Garcia-Casal MN (2014). Global maize production, utilization, and consumption. Ann. N.Y. Acad. Sci. 1312:105-112.

Rezendra WS, Beyeneb Y, Mugob S, Ndouc $E$, Gowdab $M$, Serumagad JP, Asead G, Ngolindae I, Jumbob $M D$, Oikehf SO, Olsenb $M$, Boréma A, Cruza CD, Prasannab BM (2019). Performance and yield stability of maize hybrids in stressprone environments in eastern Africa. The Crop J. 8(1): 107-118.

Subedi KD, Ma LA (2011). Corn Crop Production: Growth, Fertilization and Yield. Nova Science Publishers, Inc.
Trustinah, Iswanto R (2013). Effect of genotype and environmental interactions on mungbean results. J. Penelitian Pertanian Tanaman Pangan. 32(1): 36-42.

Wawo AH, Lestari P, Setyowati N (2019). local corn exploration in south sulawesi and study on its growth in research plot of PuslitBiologi, LIPI, Cibinong. Biota. 4(2): 79-93.

Widyastuti Y, Satoto, Rumanti IA (2013). The application of regression analysis and AMMI to evaluate the stability of rice genotype and interaction effect between genotype and environment. $J$. Informatika Pertanian. 22(1): 2127. 